\title{
GENETICS OF THE POLYCYSTIC OVARY SYNDROME
}

\author{
Gülüm KOSOVA and Margrit URBANEK \\ Division of Endocrinology, Metabolism and Molecular Medicine, Northwestern University Feinberg \\ School of Medicine, Chicago, IL 60611
}

\begin{abstract}
Polycystic ovary syndrome (PCOS) is a highly complex endocrine disorder, characterized by hyperandrogenemia, menstrual irregularities and polycystic ovaries. A strong genetic component to the etiology of PCOS is evident. However, due to the genetic and phenotypic heterogeneity of PCOS and the lack of insufficiently large cohorts, studies to identify specific contributing genes to date have yielded only few conclusive results. In this review we discuss the currnt status of the genetic analysis of PCOS including the results of numerous association studies with candidate genes involved in TGF- $\beta$ and insulin signaling, type 2 diabetes mellitus and obesity susceptibility. Furthermore, we address current challenges in genetic studies of PCOS, and the promise of new approaches, including genome-wide association studies and next-generation sequencing.
\end{abstract}

\section{Introduction}

Polycystic ovary syndrome (PCOS) is a common endocrine disorder, present in $~ 7 \%$ of reproductive age women [1], and is characterized by hyperandrogenemia, menstrual irregularities, chronic anovulation, polycystic ovaries, and reduced fertility [2]. In addition to its reproductive features, PCOS also has numerous metabolic consequences, including increased risk of obesity [3], insulin resistance (IR) [4], type 2 diabetes mellitus (T2DM) [5] and premature arteriosclerosis [6]. As such, the impact of this disorder is not just limited to reproductive age, but continues throughout life. Male and female first-degree relatives of women with PCOS are also at increased risk of developing obesity, IR and T2DM [7,8]. Therefore, PCOS and its related disorders have a broad impact on the population at large, and contribute significantly to the health burden of Western societies [9].

PCOS is a highly complex and heterogeneous disorder with significant contributions of both genetic and environmental factors. The multiple reproductive and metabolic features that define PCOS as a disorder may reflect an underlying genetic heterogeneity. This genetic heterogeneity, combined with broad variability in the diagnostic criteria, contributes to the complexity of the genetic studies of PCOS, and poses considerable challenges for identifying susceptibility genes (Box 1).

In this review, first, we briefly present different approaches and challenges in genetic studies of PCOS. Then, we discuss the current state of candidate gene association studies. We

(C) 2012 Elsevier Ireland Ltd. All rights reserved

Correspondence: Margrit Urbanek Division of Endocrinology, Metabolism and Molecular Medicine Northwestern University Feinberg School of Medicine 300 East Superior Avenue Tarry 15-717 Chicago, IL 60611 TEL: (312) 503-3658 FAX: (312) 908-9032 m-urbanek@northwestern.edu.

Publisher's Disclaimer: This is a PDF file of an unedited manuscript that has been accepted for publication. As a service to our customers we are providing this early version of the manuscript. The manuscript will undergo copyediting, typesetting, and review of the resulting proof before it is published in its final citable form. Please note that during the production process errors may be discovered which could affect the content, and all legal disclaimers that apply to the journal pertain. 
particularly emphasized eight genes with functions in TGF- $\beta$ pathway, insulin signaling, and associated with T2DM and/or obesity. These genes are among the most thoroughly investigated functional candidates for PCOS susceptibility. We will concentrate on studies published since 2007, as earlier studies were discussed in detail by us and the others (for example, see reviews [10-13]). Lastly, we discuss utilization of more recent genetic approaches that are gaining popularity among PCOS researchers, namely genome-wide association studies (GWAS) and next-generation sequencing (NGS). Although the existing studies using these approaches are still very scarce, the success of the follow-up replication studies so far points to a promising start to a new era in PCOS research.

\section{Genetic Basis of PCOS}

PCOS is a complex disorder influenced by both environmental and genetic factors. Evidence for genetic contribution includes a well-documented familial clustering of PCOS, as well as increased prevalence of its components, including hyperandrogenemia, and T2DM in firstdegree relatives of women with PCOS $[8,14]$; and a high heritability $\left(h^{2}=0.70\right)$ in a Dutch twin study [15]. Nonetheless, the mode of heritance of PCOS remains unclear, and both dominant and multigenic modes of transmission have been proposed [15-17].

\section{Genetic Association Studies of PCOS}

Association studies have been regarded as a powerful method to identify disease susceptibility loci in genetics research [18]. Although both family-based and populationbased (case-control cohorts) approaches can be employed, case-control studies have been more popular due to easier subject recruitment (no need to obtain parental information and samples), reduced costs (no need to genotype parents), and lower levels of identity by descent (IBD). To date, much of the PCOS genetic research has been based on candidate gene association studies, which have the advantage of identifying variants with relatively small effect sizes and do not require extensive genotyping (cost effective and reduced multiple testing); but, it also requires a good understanding of the disease biology and/or gene function. As has been the case for other complex phenotypes, the findings from these studies, however, have lacked consistent replication. Phenotypic heterogeneity among recruited subjects, differences in the genetic backgrounds between different populations and incomplete genotyping coverage in candidate genes are all possible factors contributing to observed inconsistencies across studies. In addition, the majority of these studies are underpowered due to inadequate sample sizes, leading to false-negative associations; furthermore, the liberal significance thresholds often used in candidate gene association studies are likely to generate false-positive findings (Box 1). Genome-wide association studies (GWAS), on the other hand, are becoming feasible in PCOS genetic studies. The GWAS approach provides the advantage of surveying large number of variants covering much of the genome at once, thus facilitating the discovery of novel genes, regardless of whether their function has previously been implicated in PCOS. However, due to the large number of loci being tested, and thus, extensive correction is required for multiple testing, GWAS need large sample sizes, and are more ideal for detecting variants with large effect sizes.

\subsection{Candidate Gene Association Studies}

3.1.1. Fibrillin-3 (FBN3) - In an earlier screen of 37 candidate genes by Urbanek et al., a PCOS susceptibility locus was mapped to chromosome 19p13.2, with the strongest evidence for association with D19S884 allele 8 (A8) [19]. Although D19S884 maps to exon 55 of the fibrillin-3 (FBN3) gene, a member of the fibrillin/LTBP (latent TGF- $\beta$ binding protein) gene family, the association with this marker was initially compelling due to its proximity ( $\sim 800$ $\mathrm{kb}$ upstream) to insulin receptor gene (INSR). However, further fine mapping in this region 
by genotyping additional microsatellites and single nucleotide polymorphisms (SNPs), and by sequencing the coding regions of all the genes within 100kb of D19S884 failed to identify any other association stronger than D19S884 A8 [20-22]. In addition, according to data from public databases (i.e. HapMap [23]), this marker falls within a recombination hotspot, and displays very limited linkage disequilibrium (LD; the biological basis for association studies). Therefore, D19S884 itself is the likely causal variant for PCOS susceptibility. Function of $F B N 3$, however, is not fully characterized. Other members in this family, $F B N 1$ and $F B N 2$, encode ubiquitously expressed extracellular matrix (ECM) proteins, and function as regulators of the TGF- $\beta$ signaling pathway by binding and sequestering cytokines in the ECM. Therefore, fibrillins are critical to the appropriate spatial and temporal availability of TGF- $\beta$ ligands [24]. As such, potential effects of D19S884 A8 on $F B N 3$ gene function is yet to be elucidated.

After its first identification, numerous studies have been published on association between D19S884 and PCOS. Our group has replicated the observed association in two independent sets of families [20,22]. In addition, we also showed association between higher fasting insulin levels and homeostatic model assessment (HOMA)-IR in women with PCOS, independent of obesity [21]. Tucci et al. also reported similar findings with the association of PCOS, despite the small sample size [25]. On the other hand, both Villundeas et al. and Prodoehl et al. failed to replicate this association in 108 PCOS patients and 66 healthy controls from Spain and Italy [26], and 173 PCOS patients and 194 controls from Australia [27], respectively.

Several studies investigated expression patterns of $F B N 3$ in humans. FBN3 expression in adult tissues is highly restricted, and localized to the specialized perifollicular stroma of follicles specifically transitioning from primordial to primary stage [28], while absent in rest of the ovarian tissues, as well as corpora lutea and human ovarian cancer cell lines [27]. Interestingly, the number of transitional follicles in PCOS ovaries were greatly reduced compared to controls, resulting in decreased amounts of FBN3 found in these tissues [28]. In addition, a recent study by Hatzirodos et al. demonstrated expression of $F B N 3$ in the stromal compartments of fetal ovaries during the first trimester of gestation when the follicles are forming, and declining significantly afterwards, being undetectable in adult ovaries [29]. This finding is particularly exciting, as it suggests that FBN3 may exert its effect during fetal development, and influence a person's predisposition to PCOS later in life, supporting previously proposed hypotheses on fetal origins for PCOS [30,31].

TGF- $\beta$ signaling pathway members are ideal candidates for PCOS, and its related metabolic phenotypes, including insulin resistance (IR), due to their roles in tissue differentiation, hormone regulation, cell proliferation, immune system, and healthy functioning of muscle, adipose and ovary tissues. In relation to the proposed role of FBN3 in TGF- $\beta$ signaling, Raja-Khan et al. studied the differences in the circulating levels of TGF- $\beta$ superfamily molecules between PCOS women, based on their D19S884 genotype. They found that PCOS women carrying D19S884 allele 8 (A8) had significantly lower circulating total TGF$\beta 1$, and higher Inhibin B and aldosterone levels, compared to PCOS women without A8 [32]. This was the first report to show the effects of a polymorphism in FBN3 on TGF- $\beta$ signaling molecules.

3.1.2. Insulin (INS)-Insulin is produced in the $\beta$-cells of the pancreas and affects multiple organ systems in the body. In the reproductive system, it stimulates ovaries to produce and secrete androgens, enhances ovarian growth, and inhibits apoptosis in the ovarian follicles, which may cause cyst formation [33,34]. Because insulin resistance, hyperinsulinaemia, and $\beta$-cell dysfunction are common features of PCOS [5], insulin, and 
the other members of insulin-signaling pathway have been considered to be candidates for PCOS.

A variable number tandem repeat (VNTR) polymorphism located in the 5' regulatory element of the insulin gene, INS, affects its transcriptional regulation, and is associated with hyperinsulinemia, fasting insulin levels, susceptibility to T2DM, birth weight, and childhood obesity and juvenile obesity (for a review, see ref. [35]). Evidence for role of INS in PCOS was first demonstrated by Waterworth et al., indicating linkage in 17 families and preferential transmission of longer (class III) alleles at this locus from fathers of PCOS patients [36]. The latter finding was replicated by Michelmore et al [37]. In addition, Ferk et al. found significant association between class III VNTR alleles and PCOS in 117 cases and 108 healthy controls from Slovenia [38]. However, these findings have not been replicated consistently, including studies with much larger data sets and different ethnic backgrounds [19,39-41]; and therefore, contribution of INS to the etiology of PCOS is still in question.

3.1.3. Insulin receptor (INSR)-The insulin receptor (INSR) has long been considered a strong candidate gene for PCOS as mutations in INSR result in hyperandrogenemia [42]. INSR is still being studied widely in order to elucidate its putative role in PCOS. The tyrosine kinase domain of INSR (exons 17-21) is of particular interest, as mutations in this domain are associated with moderate hyperinsulinaemia and insulin resistance [43]. A silent C-to-T substitution at His1058 position (designated His1085 in dbSNP) was previously shown to be associated with PCOS in a study of 99 cases and 136 controls [44]. However, replication of this association has been highly variable: two studies found increased frequency of His $1058 \mathrm{~T}$ allele in PCOS patients from China and India [45,46]; whereas two studies did not see a significant association in Korean and Turkish PCOS patients [47-49], although it should be noted that all these studies lacked power due to small sample sizes. To overcome this limitation, Ioannidis et al. combined the data from these studies for a meta analysis of the His $1058 \mathrm{C} / \mathrm{T}$ polymorphism in a total of 795 cases and 576 controls, and estimated the combined odds ratio (OR) of 1.28 (95\% confidence interval (CI) 0.88-1.85) [50], which suggests that His 1058 variation is likely not a major contributor to the etiology of PCOS.

Two other studies, however, have investigated INSR gene in a more comprehensive manner. Lee et al. sequenced the exons of INSR in 24 healthy Korean women to survey all coding variation present in the general population; 9 SNPs identified from the resequencing study were then genotyped in 134 Korean women with PCOS and 100 body mass index (BMI)matched controls. They found no significant associations, except with a novel SNP, rs2252673, for which, the minor T allele confers a modest protective effect to the carriers [48]. In contrast, Goodarzi et al. [51] selected "tag-SNPs" in the INSR gene (along with 38 other genes in insulin signaling pathway), based on Caucasian subjects in HapMap project [23], which aims to capture $>80 \%$ of all genetic variation in this population. They utilized a two-step strategy, where they first genotyped all the selected SNPs in a discovery cohort of 275 cases and 171 controls, and then proceeded to genotype the SNPs with the strongest associations in a replication cohort of 526 cases and 3,585 controls. At the discovery stage, 4 SNPs in INSR showed significant association with PCOS; however, only one of them, rs2252673, was found to be associated with PCOS in the replication cohort [51], supporting the findings of Lee et al. [48].

3.1.4. Insulin receptor substrate $\mathbf{1}$ (IRS1)—Insulin receptor substrates (IRS) are mediators in insulin signaling, acting downstream of insulin receptor as docking proteins between the receptor and the intracellular signaling molecules, making them functionally plausible candidates for PCOS susceptibility. Among the numerous polymorphisms identified in IRS1, Gly972Arg is the most commonly studied polymorphism for its possible 
association with PCOS; however the outcome has been highly variable, with examples of both presence [52-54] and absence [55-58] of significant association found in current literature. Similar to the INSR His1058 polymorphism analysis, Ioannidis et al. performed meta analysis for association with IRS1 Gly972Arg polymorphism in a combined set of 889 PCOS cases and 1,303 controls, obtained from 11 studies. They found that the Arg972 allele is a risk factor for PCOS, with an OR of 1.77 (95\% CI 1.28-2.45), and suggested that PCOS susceptibility due to the Arg972 is mediated through increased levels of fasting insulin [50].

3.1.5. Transcription factor 7-like 2 (TCF7L2) - TCF7L2 is a transcription factor in the wnt signaling pathway, which is critical for embryogenesis and cell proliferation, including development of the pancreas and the islets. Associations between two SNPs, rs7903146 and rs 12255372 (in introns 3 and 4, respectively) and T2DM have been replicated in numerous studies, and are the SNPs that provide among the strongest evidence of association with T2DM $[59,60]$.

Barber et al. was the first to test associations between the two T2DM associated SNPs in two large data sets; one is a UK British/Irish cohort of 369 PCOS cases and 2,574 controls, and the second set of 540 women with PCOS symptoms and 1,083 controls chosen from the Northern Finland Birth Cohort of 1966. However, they did not find a significant association either with PCOS or androgen levels; and therefore concluded that genetic variation influencing $\beta$-cell function is not a major predictor of PCOS pathogenesis [61]. A recent study by Ewens et al. also evaluated the association with the same two SNPs and PCOS using 400 probands and affected sisters, as well as 395 PCOS patients and 171 controls of European descent, and failed to detect significant associations with PCOS or $\beta$-cell function (measured by HOMA-IR and HOMA-\% $\beta$ ) [62]. Likewise, two studies conducted in Asian populations to date have failed to provide any evidence of association between variants in TCF7L2 with PCOS $[63,64]$.

On the other hand, Christopoulos et al. reported a modest association between rs7903146 and PCOS in 183 cases and 148 controls from Greece [65], whereas Tan et al. detected association with only obesity related traits (body weight, BMI, waist circumference), but not with insulin resistance, androgen levels or other PCOS specific symptoms, such as hirsutism, amenorrhea, acne and polycystic ovaries [66]. Biyasheva et al. studied the entire genomic region of TCF7L2 by tagging the entire gene with 58 SNPs to test for associations with PCOS in 624 cases and 553 controls, as well as seven PCOS related reproductive and metabolic quantitative traits. Although T2DM locus also failed to provide evidence of association with PCOS as in the studies described above, another variant located approximately $100 \mathrm{~kb}$ downstream, rs11196236, was associated with PCOS, particularly in normoglycemic patients, even after adjustment for multiple testing [67]. In contrast, T2DM locus showed significant association with proinsulin:insulin molar ratio (marker for $\beta$-cell function) in dysglycemic PCOS patients. The authors therefore concluded that different variation in the same gene might result in susceptibility to different phenotypes [67].

3.1.6. Calpain 10 (CAPN10)-CAPN10, which encodes a cysteine protease, was discovered as a susceptibility locus for T2DM through positional cloning [68,69], with two haplotypes (denoted as 112 and 121), comprised of three SNPs (UCSNP-43, -19 and -63) were identified to confer an increased risk for susceptibility to T2DM to individuals heterozygous for both haplotypes [69]. Subsequently, CAPN1O was found to play a role in insulin secretion and action [70,71]. Although the evidence for association with T2DM has weakened recently due to the fact that no significant association signal was observed in any GWAS [72], CAPN1O remained as one of the candidate genes most frequently investigated in PCOS research. Despite the lack of significant associations in earlier studies (for a 
review, see ref. [11]), more recent studies in diverse ethnic groups support a putative role for CAPN10 in PCOS.

Gonzalez et al. was first to report a significant association between UCSNP-44 and PCOSrelated phenotypes; as well as CAPN1O haplotypes and other phenotypic characteristics of PCOS (including hypercholesterolemia and hirsutism) in Spanish patients [73,74]. A study in a Turkish population has also found significant association between UCSNP-44 and PCOS, and other metabolic feature of PCOS, including androgen and insulin levels [75]. Other studies demonstrated associations of T2DM risk alleles (UCSNP-43, -19 and -63; alone or in combination) with PCOS in Germans [76], Chileans [77] and Koreans [78]; and also with metabolic syndrome in Brazilian PCOS patients [79]. However, it should be noted that many of these studies have relatively small sample sizes, therefore, either replication in a larger sample, or meta analysis (similar to INSR and IRSI) should be performed in order to provide stronger support to this argument.

3.1.7 Fat and obesity associated gene (FTO)—Recent genome-wide association studies identified variation in the FTO gene strongly associated with childhood and adult obesity [80-82] in individuals with European ancestry. Subsequently, these findings have also been replicated across many other ethnically diverse populations (for examples, see refs. [83-87]). Similar to T2DM, obesity is also a key feature in the etiology of PCOS, and is observed in approximately 50\% of PCOS patients. Frequent co-occurrence of PCOS and obesity raises the possibility of shared genetic predispositions to both traits, and therefore, variants shown to influence BMI and are risk factors for obesity are also plausible candidates for PCOS.

Barber et al. studied whether genetic variation in FTO also influences risk of PCOS in 463 cases and 1,336 controls from Britain. They identified an association between the SNP rs9939609 and PCOS, however, this association was largely attenuated when BMI was included in the analyses as a covariate, suggesting that the observed PCOS risk can be attributed to increased adiposity [88]. Yan et al. reported similar results in a Chinese cohort, where an initial significant association between rs9939609 and PCOS was attenuated after adjustment for BMI [89]; and Attaoua et al. found a significant association with PCOS only in patients exhibiting obesity or metabolic syndrome [90]. Other studies either did not find direct association with PCOS [91], or did not consider the association between FTO and PCOS per se [66,92,93]; but all reported significant associations with BMI in PCOS patients, therefore, it seems likely that possible effects of FTO in PCOS is limited to the metabolic phenotypes.

The nature of the relationship between FTO and PCOS, however, remains unclear because phenotypic manifestations of PCOS are often confounded by BMI (i.e. possible improvement of the reproductive phenotypes of PCOS after weight loss [94]). Both Tan et al. and Kowalska et al. showed that the average increase in BMI attributable to FTO risk alleles is greater in PCOS patients than it is in normal population, suggesting FTO variants are greater risk factors for obesity in PCOS [66,92]. We should note that, however, this claim should be regarded with caution given that samples sizes used to estimate the relative effects of FTO in PCOS in both studies are much smaller than those used in GWAS of obesity. It is therefore possible that their estimated effect sizes are inflated.

3.1.8. Sex hormone-binding globulin (SHBG) $-S H B G$ is a glycoprotein that is synthesized in the liver, and regulates bioavailability of androgens by binding sex steroids [95]. Previous studies have demonstrated that decreased serum SHBG levels are associated with incread risk of PCOS [96-102] in women, as well as IR and T2DM in both men and women $[103,104]$. (TAAAA)n pentanucleotide repeat polymorphism in the promoter region 
have been shown to affect transcription efficiency of $S H B G$, as longer repeat numbers at this locus resulting in decreased serum SHBG levels [98,102,105-107]. The hypothesis that $S H B G$ (TAAAA)n polymorphism is a susceptibility locus for PCOS, however, is only supported by the studies of Xita et al., conducted in two small case-control cohorts in Greece, where they showed a positive associations between the longer alleles of (TAAAA)n repeat polymorphism (>8 repeats) and PCOS [101,102]. Others reported lack of association between PCOS and $S H B G$ variants (including this repeat polymorphism) in diverse populations with European and Asian descent ([96-100]; Urbanek et al., personal communication). These results indicate that SHBG likely influence PCOS phenotype indirectly, perhaps by altering the bioavailable androgen levels in the target tissues, however, genetic variation in $S H B G$ is not associated with PCOS per se.

In summary, although a large number of candidate gene studies have been conducted for PCOS, findings for these studies have been mostly inconclusive. Furthermore, the significance of even the most robust of these studies needs to be regarded with caution since the evidence for association remains relatively modest. None of the studies are significant at the genome-wide level $\left(P<1 \times 10^{-8}\right)$, the gold standard for genetic studies. While a strict requirement for significance levels to reach this threshold is most likely too conservative, some correction for multiple testing must be applied. The extent of correction for multiple testing needs to be specific for each study, and should take into account both the number of phenotypes, as well as the number of independent genetic loci being tested. Independent genetic loci could be individual variants with little to none correlation (linkage disequilibrium) between them, or haplotype blocks.

\subsection{Genome-wide Association (GWA) Studies}

To date, GWAS have been very fruitful for identifying susceptibility loci for a wide range of complex human diseases including T2DM, obesity, asthma, psychiatric disorders, and fertility [108-112]. Implementing this method to PCOS research, however, has only just begun, owing to a lack of sufficiently large data sets and the phenotypic heterogeneity inherent to PCOS. Because of these reasons, there is only one published GWAS of PCOS to date. Chen et al. carried out a GWAS with a discovery group of 744 women with PCOS and 895 controls of Han Chinese ancestry [113]. Loci showing strong association in the first stage were then genotyped in two independent replication cohorts of 2,840 cases and 5,012 controls of northern Han Chinese ancestry, and 498 cases and 780 controls of southern and central Han Chinese decent. Three distinct regions were designated PCOS susceptibility loci after the replication stage, and showed strong evidence of association with PCOS in the combined meta-analysis $\left(P_{\text {meta }}<1 \times 10^{-18}\right)$ [113]. The first locus is located on chromosome 2p16.3, and contains two genes, GTF2A1L (TFII1-alpha and beta like factor) and LHCGR (luteinizing hormone/choriogonadotropin receptor). Luteinizing hormone (LH) initiates ovulation by releasing the mature oocyte through stimulating ovaries to produce estrogen and progesterone; choriogonadotropin (hCG) functions in maintenance of pregnancy. Therefore, $L H C G R$ has a crucial function in ovarian physiology and reproductive processes. Interestingly, this locus is also $200 \mathrm{~kb}$ downstream of FSHR (follicle stimulating hormone receptor) gene, which is another plausible PCOS candidate due to its role in development of ovarian follicles. FSHR contains another group of SNPs (independent of LHCGR locus) which show evidence for association with PCOS just below the level of genome-wide significance. The second locus is located on chromosome $2 \mathrm{p} 21$, and two independently associated SNPs at this locus are located in the THADA (thyroid adenoma associated) gene. This region has previously been implicated in T2DM susceptibility in Europeans [114]. Lastly, the third locus is located on chromosome 9q33.3, in the DENND1A (DENN domaincontaining protein 1A) gene, which encodes a protein involved in endosomal membrane trafficking [115], and also has a function in guanine exchange for the small GTPase Rab35. 
Because $D E N N D 1 A$ affects a wide range of physiological processes, and is expressed ubiquitously, it is expected that it might also influence some of the many organ systems PCOS affects, perhaps through altered activity of endoplasmic reticulum aminopeptidase 1 (ERAPI) [113]. Chen et al. also checked the significance of the SNPs in their array data that are located in 51 previously reported PCOS candidate genes. Among the genes discussed in this review, INSR had 10 SNPs located within $\sim 45 \mathrm{~kb}$ region with $P$-values $<0.05$ (min $P=7 \times 10^{-5}$ ); however the two SNPs mentioned earlier in the previous section were not on the genotyping array. FTO and $C A P N 10$ also had numerous SNPs with $P$-values $<0.05$, however the strength of the association was much weaker ( $\min P=0.017$ and 0.043 , respectively). Obesity-associated rs9939609 SNP in FTO had a $P$-value of 0.039 , whereas two previously studied SNPs in $C A P N 10$ (UCSNP-43 and -44) both had $P$-values $>0.1$. There were no significant associations with 16 SNPs in IRS1 and 37 SNPs TCF7L2 genes; association with variants in $F B N 3, I N S$ and $S H B G$ were not reported in this study. Overall, after the three primary genetic regions identified in the GWAS, insulin receptor is one of the most promising candidate gene for PCOS susceptibility in Asian populations [113].

While the GWAS carried out by Chen et al. is one of the biggest genetic studies of PCOS to date, replication of these findings in different populations is a key to validate their roles in PCOS. Four studies have been published within last year investigating the effects of the three identified loci on PCOS in women with European descent [116-119]. Lerchbaum et al. and Eriksen et al. studies only genotyped three SNPs (most significantly associated SNPs at each of the three loci), and both reported a similar trend with the $\mathrm{G}$ allele at rs 2479106 in $D E N N D 1 A$ being associated with increased risk for PCOS. They found no significant association with either of $L H C G R$ or THADA loci [116,117]. On the other hand, in the studies by Goodarzi et al. and Welt et al., all seven SNPs were considered for the analyses, one SNP in LHCGR, and three SNPs in both THADA and DENND1A [118,119]. Both studies reported significant associations with rs 10818854 in $D E N N D 1 A\left(P=6.5 \times 10^{-8}\right.$ and $3.3 \times 10^{-4}$,respectively), but not with rs 2479106 in the same gene. Goodarzi et al. also reported significant associations with rs 12468394 in THADA $\left(P=9.4 \times 10^{-3}\right)[118]$, whereas Welt et al. only reported increased testosterone levels associated with this marker [119]. There were no significant associations with the LHCGR locus in either study, however the authors have also noted that due to the low minor allele frequency at this marker in the European populations, the power to detect an effect of a similar size to Chen et al. was considerably reduced $[118,119]$.

Despite the fact that associated SNPs in DENND1A differed between the studies, due to the success of replication attempts in both Asian and European populations, DENND1A has gained recognition as a true PCOS susceptibility gene. We should underline that, $D E N N D 1 A$ is a novel gene identified through GWAS, and implicated in etiology of PCOS for the first time, without any a priori knowledge. This demonstrates the utility of GWAS in generating novel hypotheses to understand the genetics of complex phenotypes like PCOS. We believe, with the continuous development of new and more powerful analytical tools, decreasing costs, and availability of larger data sets, the GWAS approach followed by replication studies will be employed more often in PCOS research. In fact, at least two additional PCOS GWAS will be completed in the near future. These studies will help to move the PCOS field forward, and add greatly to our understanding of the genetic underpinnings of this disorder.

\section{Future Directions for the PCOS Genetic Research}

Although there still a number of strong PCOS susceptibility candidate genes under close scrutiny, and a promising start to GWAS, we are still far from fully understanding all the genetic contributions to this disorder. However, with the recent technological advancements 
and availability of newer analytical methods that are also cost-effective, research in genetics is rapidly moving towards a much more exciting era. In particular, development of nextgeneration sequencing (NGS) methods has revolutionized the field by offering wide range of applications available to researchers. Not surprisingly, this will also influence the approaches commonly used in PCOS research. For example, targeted and/or whole-genome resequencing studies will likely replace the current SNP-based association studies, which will circumvent the problem of incomplete coverage of genes, as this has been a downfall in nearly all association studies to date. In addition, genome sequencing will enable genotyping the rare variants. The contribution of rare variants to complex diseases is currently not well understood and still under debate, as the SNP selection in many association studies (and in commercially available genotyping platforms) are targeted for common variants (with minor allele frequencies higher than 5-10\%). More importantly, sequencing will facilitate the identification of the causal variants, which, in the long run, will also help to address the long standing common disease-common variant vs. common disease-rare variant hypothesis [120].

Other applications of NGS are also possible. Based on a similar technology, RNA sequencing (RNA-seq) allows more robust analysis of transcriptomes, and has becoming increasingly popular. The advantages and applications of RNA-seq are countless. First, it provides the complete expression profile of a given transcriptome, including, genes expressed at very low levels, alternative splice variants and previously unidentified transcripts; and compared to microarray based approaches, the range of expression that can be detected and quantified is much greater. In addition, because it is a sequencing-based method, sequence variations in the coding regions of the genome can be detected simultaneously [121]. Therefore, this method can be used to search for possible perturbations in expression of certain genes (for example, members of TGF- $\beta$ pathway), or discover other genes whose function may be altered due to abnormal expression or splice variation in tissues of women with PCOS, while the same sequence data can be used to look for coding variations that might be responsible for the functional differences. Last, but not least, the effect of intrauterine environment, particularly androgen exposure during fetal development and epigenetic alterations during this time, have been proposed as risk factors for PCOS later in life [122]. It is beyond the scope if this review to discuss the validity of this argument, however, we note that, studies looking at differences in DNA methylation profiles between PCOS cases and controls are increasing in number. Along with NGS, methods for genome-wide DNA methylation analysis at a single base pair resolution are evolving quickly [123]. Therefore, it will soon be more feasible to carry out studies with sufficiently large sample sizes, in different tissue types and in a genome-wide manner.

\section{Conclusions}

Although a considerable progress has been made in identifying PCOS susceptibility genes in the last decade, this progress has been much slower in comparison to mapping studies of some of the other complex human traits, such as T2DM and obesity. Contribution of many of the studied genes remains controversial or inconclusive, owing to lack of consistent replication. There are several possible reasons for this. First, due to complex nature of PCOS, and variability in PCOS diagnosis criteria, there is a large phenotypic heterogeneity across different studies. Second, the majority of the studies are considerably underpowered due to small sample sizes (i.e. $<300$ affected women), which can lead to false positive and false negative associations. Third, many candidate gene studies assessed the effects of only few variants in each gene, rather than surveying the variation in the entire gene. Increasing the sample sizes, as well as including power analysis for detecting associations in a sample of a given size are necessary in order to improve the quality of gene association studies of PCOS. However, efforts to increase sample size often compromise the phenotypic 
homogeneity in the group. For the purposes of genetic association studies, it is also important to define stricter and more uniform diagnostic criteria. If larger sample size is not attainable, multi-center collaborative studies and meta-analyses, or studies of intermediate phenotypes can be opted as alternative approaches. Given the availability of common human genetic variation data (i.e. HapMap [23], 1,000 genomes [124], Human Genome Diversity Project [125]), and relatively inexpensive high-throughput genotyping methods, association studies should be designed to capture as much genetic variation as possible in a given gene, rather than just a few SNPs. In addition, haplotypes associated with PCOS are more likely to carry the functional variant, and decrease the chance of false-positive findings. Likewise, using gene- or pathway-level tests, and looking for associations within gene networks, rather than with individual SNPs may increase the chances of finding true susceptibility genes (particularly those with small effect size), and can lead to better understanding of the complex genetic architecture of PCOS. Lastly, with remarkable advancements in gene sequencing technology today, and development of new analytical methods, there is a lot to look forward to in the coming years for delineation of genetic risk factors in PCOS.

\section{Abbreviations}

AUCI:

BMI:

CAPN10:

CI:

ECM:

FAI:

FBN3:

FSH:

FTO:

GWAS:

HOMA-\% $\beta$ :

HOMA-IR:

IBD:

INS:

INSR:

IR:

IRS:

LD:

LTBP:

NGS:

OR:

PCOS:

RNA-seq:

SNP:
Area under the curve of insulin response

Body mass index

Calpain 10

Confidence interval

Extracellular matrix

Free androgen index

Fibrillin 3

Follicle stimulating hormone

Fat-mass and obesity associated gene

Genome-wide association studies

Homeostatic model assessment, $\beta$-cell function

Homeostatic model assessment, insulin resistance

Identity by descent

Insulin

Insulin receptor

Insulin resistance

Insulin receptor substrate

Linkage disequilibrium

Latent TGF- $\beta$ binding protein

Next-generation sequencing

Odds ratio

Polycystic ovary syndrome

RNA sequencing

Single nucleotide polymorphism 
T2DM: $\quad$ Type 2 diabetes mellitus

TCF7L2: $\quad$ Transcription factor 7-like 2

TGF- $\beta$ : $\quad$ Transforming growth factor, beta

VNTR: $\quad$ Variable number tandem repeat polymorphism

\section{REFERENCES}

[1]. Knochenhauer ES, Key TJ, Kahsar-Miller M, Waggoner W, Boots LR, Azziz R. Prevalence of the polycystic ovary syndrome in unselected black and white women of the southeastern United States: a prospective study. J Clin Endocrinol Metab. 1998; 83:3078-82. [PubMed: 9745406]

[2]. Zawadzki, JK.; Dunaif, A. Polycystic ovary syndrome. Blackwell Scientific; Cambridge, MA: 1992. Diagnostic criteria for polycystic ovary syndrome: towards a rational approach; $p$. 377-384.

[3]. Hoeger K. Obesity and weight loss in polycystic ovary syndrome. Obstet Gynecol Clin North Am. 2001; 28:85-97. vi-vii. [PubMed: 11293006]

[4]. Cotrozzi G, Matteini M, Relli P, Lazzari T. Hyperinsulinism and insulin resistance in polycystic ovarian syndrome: a verification using oral glucose, I.V. Glucose and tolbutamide. Acta Diabetol Lat. 1983; 20:135-42. [PubMed: 6224386]

[5]. Legro RS, Kunselman AR, Dodson WC, Dunaif A. Prevalence and predictors of risk for type 2 diabetes mellitus and impaired glucose tolerance in polycystic ovary syndrome: a prospective, controlled study in 254 affected women. J Clin Endocrinol Metab. 1999; 84:165-9. [PubMed: 9920077]

[6]. Talbott EO, Guzick DS, Sutton-Tyrrell K, McHugh-Pemu KP, Zborowski JV, Remsberg KE, Kuller LH. Evidence for association between polycystic ovary syndrome and premature carotid atherosclerosis in middle-aged women. Arterioscler Thromb Vasc Biol. 2000; 20:2414-21. [PubMed: 11073846]

[7]. Legro RS, Bentley-Lewis R, Driscoll D, Wang SC, Dunaif A. Insulin resistance in the sisters of women with polycystic ovary syndrome: association with hyperandrogenemia rather than menstrual irregularity. J Clin Endocrinol Metab. 2002; 87:2128-33. [PubMed: 11994352]

[8]. Ehrmann DA, Kasza K, Azziz R, Legro RS, Ghazzi MN. Effects of race and family history of type 2 diabetes on metabolic status of women with polycystic ovary syndrome. J Clin Endocrinol Metab. 2005; 90:66-71. [PubMed: 15507516]

[9]. Azziz R, Dumesic DA, Goodarzi MO. Polycystic ovary syndrome: an ancient disorder? Fertil Steril. 2011; 95:1544-8. [PubMed: 20979996]

[10]. Urbanek M, Spielman RS. Genetic analysis of candidate genes for the polycystic ovary syndrome. Curr Opin in Endocrin Diabetes. 2002; 9:492-501.

[11]. Urbanek M. The genetics of the polycystic ovary syndrome. Nat Clin Pract Endocrinol Metab. 2007; 3:103-11. [PubMed: 17237837]

[12]. Simoni M, Tempfer CB, Destenaves B, Fauser BC. Functional genetic polymorphisms and female reproductive disorders: Part I: Polycystic ovary syndrome and ovarian response. Hum Reprod Update. 2008; 14:459-84. [PubMed: 18603647]

[13]. Goodarzi MO, Azziz R. Diagnosis, epidemiology, and genetics of the polycystic ovary syndrome. Best Pract Res Clin Endocrinol Metab. 2006; 20:193-205. [PubMed: 16772151]

[14]. Legro RS, Driscoll D, Strauss JF 3rd, Fox J, Dunaif A. Evidence for a genetic basis for hyperandrogenemia in polycystic ovary syndrome. Proc Natl Acad Sci U S A. 1998; 95:1495660. [PubMed: 9843997]

[15]. Vink JM, Sadrzadeh S, Lambalk CB, Boomsma DI. Heritability of polycystic ovary syndrome in a Dutch twin-family study. J Clin Endocrinol Metab. 2006; 91:2100-4. [PubMed: 16219714]

[16]. Kahsar-Miller M, Azziz R. The development of the polycystic ovary syndrome: family history as a risk factor. Trends Endocrinol Metab. 1998; 9:55-8. [PubMed: 18406241] 
[17]. Franks S, McCarthy M. Genetics of ovarian disorders: polycystic ovary syndrome. Rev Endocr Metab Disord. 2004; 5:69-76. [PubMed: 14966390]

[18]. Risch N, Merikangas K. The future of genetic studies of complex human diseases. Science. 1996; 273:1516-7. [PubMed: 8801636]

[19]. Urbanek M, Legro RS, Driscoll DA, Azziz R, Ehrmann DA, Norman RJ, Strauss JF 3rd, Spielman RS, Dunaif A. Thirty-seven candidate genes for polycystic ovary syndrome: strongest evidence for linkage is with follistatin. Proc Natl Acad Sci U S A. 1999; 96:8573-8. [PubMed: 10411917]

[20]. Stewart DR, Dombroski BA, Urbanek M, Ankener W, Ewens KG, Wood JR, Legro RS, Strauss JF 3rd, Dunaif A, Spielman RS. Fine mapping of genetic susceptibility to polycystic ovary syndrome on chromosome 19p13.2 and tests for regulatory activity. J Clin Endocrinol Metab. 2006; 91:4112-7. [PubMed: 16868051]

[21]. Urbanek M, Sam S, Legro RS, Dunaif A. Identification of a polycystic ovary syndrome susceptibility variant in fibrillin-3 and association with a metabolic phenotype. J Clin Endocrinol Metab. 2007; 92:4191-8. [PubMed: 17785364]

[22]. Urbanek M, Woodroffe A, Ewens KG, Diamanti-Kandarakis E, Legro RS, Strauss JF 3rd, Dunaif A, Spielman RS. Candidate gene region for polycystic ovary syndrome on chromosome 19p13.2. J Clin Endocrinol Metab. 2005; 90:6623-9. [PubMed: 16091490]

[23]. A haplotype map of the human genome. Nature. 2005; 437:1299-320. [PubMed: 16255080]

[24]. Ramirez F, Sakai LY. Biogenesis and function of fibrillin assemblies. Cell Tissue Res. 2010; 339:71-82. [PubMed: 19513754]

[25]. Tucci S, Futterweit W, Concepcion ES, Greenberg DA, Villanueva R, Davies TF, Tomer Y. Evidence for association of polycystic ovary syndrome in caucasian women with a marker at the insulin receptor gene locus. J Clin Endocrinol Metab. 2001; 86:446-9. [PubMed: 11232039]

[26]. Villuendas G, Escobar-Morreale HF, Tosi F, Sancho J, Moghetti P, San Millan JL. Association between the D19S884 marker at the insulin receptor gene locus and polycystic ovary syndrome. Fertil Steril. 2003; 79:219-20. [PubMed: 12524094]

[27]. Prodoehl MJ, Hatzirodos N, Irving-Rodgers HF, Zhao ZZ, Painter JN, Hickey TE, Gibson MA, Rainey WE, Carr BR, Mason HD, Norman RJ, Montgomery GW, Rodgers RJ. Genetic and gene expression analyses of the polycystic ovary syndrome candidate gene fibrillin-3 and other fibrillin family members in human ovaries. Mol Hum Reprod. 2009; 15:829-41. [PubMed: 19692420]

[28]. Jordan CD, Bohling SD, Charbonneau NL, Sakai LY. Fibrillins in adult human ovary and polycystic ovary syndrome: is fibrillin-3 affected in PCOS? J Histochem Cytochem. 2010; 58:903-15. [PubMed: 20855553]

[29]. Hatzirodos N, Bayne RA, Irving-Rodgers HF, Hummitzsch K, Sabatier L, Lee S, Bonner W, Gibson MA, Rainey WE, Carr BR, Mason HD, Reinhardt DP, Anderson RA, Rodgers RJ. Linkage of regulators of TGF- $\{$ beta $\}$ activity in the fetal ovary to polycystic ovary syndrome. FASEB J. 2011

[30]. Abbott DH, Barnett DK, Bruns CM, Dumesic DA. Androgen excess fetal programming of female reproduction: a developmental aetiology for polycystic ovary syndrome? Hum Reprod Update. 2005; 11:357-74. [PubMed: 15941725]

[31]. Ibanez L, Valls C, Potau N, Marcos MV, de Zegher F. Polycystic ovary syndrome after precocious pubarche: ontogeny of the low-birthweight effect. Clin Endocrinol (Oxf). 2001; 55:667-72. [PubMed: 11894979]

[32]. Raja-Khan N, Kunselman AR, Demers LM, Ewens KG, Spielman RS, Legro RS. A variant in the fibrillin-3 gene is associated with TGF-beta and inhibin B levels in women with polycystic ovary syndrome. Fertil Steril. 2010; 94:2916-9. [PubMed: 20630504]

[33]. Poretsky L, Cataldo NA, Rosenwaks Z, Giudice LC. The insulin-related ovarian regulatory system in health and disease. Endocr Rev. 1999; 20:535-82. [PubMed: 10453357]

[34]. Baillargeon JP, Nestler JE. Commentary: polycystic ovary syndrome: a syndrome of ovarian hypersensitivity to insulin? J Clin Endocrinol Metab. 2006; 91:22-4. [PubMed: 16263814]

[35]. Pugliese A, Miceli D. The insulin gene in diabetes. Diabetes Metab Res Rev. 2002; 18:13-25. [PubMed: 11921414] 
[36]. Waterworth DM, Bennett ST, Gharani N, McCarthy MI, Hague S, Batty S, Conway GS, White D, Todd JA, Franks S, Williamson R. Linkage and association of insulin gene VNTR regulatory polymorphism with polycystic ovary syndrome. Lancet. 1997; 349:986-90. [PubMed: 9100625]

[37]. Michelmore K, Ong K, Mason S, Bennett S, Perry L, Vessey M, Balen A, Dunger D. Clinical features in women with polycystic ovaries: relationships to insulin sensitivity, insulin gene VNTR and birth weight. Clin Endocrinol (Oxf). 2001; 55:439-46. [PubMed: 11678825]

[38]. Ferk P, Perme MP, Gersak K. Insulin gene polymorphism in women with polycystic ovary syndrome. J Int Med Res. 2008; 36:1180-7. [PubMed: 19094425]

[39]. Calvo RM, Telleria D, Sancho J, San Millan JL, Escobar-Morreale HF. Insulin gene variable number of tandem repeats regulatory polymorphism is not associated with hyperandrogenism in Spanish women. Fertil Steril. 2002; 77:666-8. [PubMed: 11937112]

[40]. Powell BL, Haddad L, Bennett A, Gharani N, Sovio U, Groves CJ, Rush K, Goh MJ, Conway GS, Ruokonen A, Martikainen H, Pouta A, Taponen S, Hartikainen AL, Halford S, Zeggini E, Jarvelin MR, Franks S, McCarthy MI. Analysis of multiple data sets reveals no association between the insulin gene variable number tandem repeat element and polycystic ovary syndrome or related traits. J Clin Endocrinol Metab. 2005; 90:2988-93. [PubMed: 15705917]

[41]. Xu Y, Wei Z, Zhang Z, Xing Q, Hu P, Zhang X, Gao G, Wang Y, Gao Q, Yi L, Cao Y. No association of the insulin gene VNTR polymorphism with polycystic ovary syndrome in a Han Chinese population. Reprod Biol Endocrinol. 2009; 7:141. [PubMed: 19948072]

[42]. Moller DE, Cohen O, Yamaguchi Y, Assiz R, Grigorescu F, Eberle A, Morrow LA, Moses AC, Flier JS. Prevalence of mutations in the insulin receptor gene in subjects with features of the type A syndrome of insulin resistance. Diabetes. 1994; 43:247-55. [PubMed: 8288049]

[43]. Taylor SI, Cama A, Accili D, Barbetti F, Quon MJ, de la Luz Sierra M, Suzuki Y, Koller E, Levy-Toledano R, Wertheimer E, et al. Mutations in the insulin receptor gene. Endocr Rev. 1992; 13:566-95. [PubMed: 1330507]

[44]. Siegel S, Futterweit W, Davies TF, Concepcion ES, Greenberg DA, Villanueva R, Tomer Y. A $\mathrm{C} / \mathrm{T}$ single nucleotide polymorphism at the tyrosine kinase domain of the insulin receptor gene is associated with polycystic ovary syndrome. Fertil Steril. 2002; 78:1240-3. [PubMed: 12477518]

[45]. Chen ZJ, Shi YH, Zhao YR, Li Y, Tang R, Zhao LX, Chang ZH. Correlation between single nucleotide polymorphism of insulin receptor gene with polycystic ovary syndrome. Zhonghua Fu Chan Ke Za Zhi. 2004; 39:582-5. [PubMed: 15498182]

[46]. Mukherjee S, Shaikh N, Khavale S, Shinde G, Meherji P, Shah N, Maitra A. Genetic variation in exon 17 of INSR is associated with insulin resistance and hyperandrogenemia among lean Indian women with polycystic ovary syndrome. Eur J Endocrinol. 2009; 160:855-62. [PubMed: 19211708]

[47]. Lee EJ, Yoo KJ, Kim SJ, Lee SH, Cha KY, Baek KH. Single nucleotide polymorphism in exon 17 of the insulin receptor gene is not associated with polycystic ovary syndrome in a Korean population. Fertil Steril. 2006; 86:380-4. [PubMed: 16806206]

[48]. Lee EJ, Oh B, Lee JY, Kimm K, Lee SH, Baek KH. A novel single nucleotide polymorphism of INSR gene for polycystic ovary syndrome. Fertil Steril. 2008; 89:1213-20. [PubMed: 17658524]

[49]. Unsal T, Konac E, Yesilkaya E, Yilmaz A, Bideci A, Ilke Onen H, Cinaz P, Menevse A. Genetic polymorphisms of FSHR, CYP17, CYP1A1, CAPN10, INSR, SERPINE1 genes in adolescent girls with polycystic ovary syndrome. J Assist Reprod Genet. 2009; 26:205-16. [PubMed: 19387820]

[50]. Ioannidis A, Ikonomi E, Dimou NL, Douma L, Bagos PG. Polymorphisms of the insulin receptor and the insulin receptor substrates genes in polycystic ovary syndrome: a Mendelian randomization meta-analysis. Mol Genet Metab. 2010; 99:174-83. [PubMed: 19926323]

[51]. Goodarzi MO, Louwers YV, Taylor KD, Jones MR, Cui J, Kwon S, Chen YD, Guo X, Stolk L, Uitterlinden AG, Laven JS, Azziz R. Replication of association of a novel insulin receptor gene polymorphism with polycystic ovary syndrome. Fertil Steril. 2011; 95:1736-1741. e11. [PubMed: 21300347]

[52]. Christopoulos P, Mastorakos G, Gazouli M, Deligeoroglou E, Katsikis I, Diamanti-Kandarakis E, Panidis D, Creatsas G. Study of association of IRS-1 and IRS-2 genes polymorphisms with 
clinical and metabolic features in women with polycystic ovary syndrome. Is there an impact? Gynecol Endocrinol. 2010; 26:698-703. [PubMed: 20210696]

[53]. Baba T, Endo T, Sata F, Honnma H, Kitajima Y, Hayashi T, Manase K, Kanaya M, Yamada H, Minakami H, Kishi R, Saito T. Polycystic ovary syndrome is associated with genetic polymorphism in the insulin signaling gene IRS-1 but not ENPP1 in a Japanese population. Life Sci. 2007; 81:850-4. [PubMed: 17719609]

[54]. Dilek S, Ertunc D, Tok EC, Erdal EM, Aktas A. Association of Gly972Arg variant of insulin receptor substrate-1 with metabolic features in women with polycystic ovary syndrome. Fertil Steril. 2005; 84:407-12. [PubMed: 16084882]

[55]. Valdes P, Cerda A, Barrenechea C, Kehr M, Soto C, Salazar LA. No association between common Gly972Arg variant of the insulin receptor substrate-1 and polycystic ovary syndrome in Southern Chilean women. Clin Chim Acta. 2008; 390:63-6. [PubMed: 18222120]

[56]. Villuendas G, Botella-Carretero JI, Roldan B, Sancho J, Escobar-Morreale HF, San Millan JL. Polymorphisms in the insulin receptor substrate-1 (IRS-1) gene and the insulin receptor substrate-2 (IRS-2) gene influence glucose homeostasis and body mass index in women with polycystic ovary syndrome and non-hyperandrogenic controls. Hum Reprod. 2005; 20:3184-91. [PubMed: 16037106]

[57]. Witchel SF, Kahsar-Miller M, Aston CE, White C, Azziz R. Prevalence of CYP21 mutations and IRS1 variant among women with polycystic ovary syndrome and adrenal androgen excess. Fertil Steril. 2005; 83:371-5. [PubMed: 15705377]

[58]. Lin TC, Yen JM, Gong KB, Kuo TC, Ku DC, Liang SF, Wu MJ. Abnormal glucose tolerance and insulin resistance in polycystic ovary syndrome amongst the Taiwanese population- not correlated with insulin receptor substrate-1 Gly972Arg/Ala513Pro polymorphism. BMC Med Genet. 2006; 7:36. [PubMed: 16603055]

[59]. Grant SF, Thorleifsson G, Reynisdottir I, Benediktsson R, Manolescu A, Sainz J, Helgason A, Stefansson H, Emilsson V, Helgadottir A, Styrkarsdottir U, Magnusson KP, Walters GB, Palsdottir E, Jonsdottir T, Gudmundsdottir T, Gylfason A, Saemundsdottir J, Wilensky RL, Reilly MP, Rader DJ, Bagger Y, Christiansen C, Gudnason V, Sigurdsson G, Thorsteinsdottir U, Gulcher JR, Kong A, Stefansson K. Variant of transcription factor 7-like 2 (TCF7L2) gene confers risk of type 2 diabetes. Nat Genet. 2006; 38:320-3. [PubMed: 16415884]

[60]. Groves CJ, Zeggini E, Minton J, Frayling TM, Weedon MN, Rayner NW, Hitman GA, Walker M, Wiltshire S, Hattersley AT, McCarthy MI. Association analysis of 6,736 U.K. subjects provides replication and confirms TCF7L2 as a type 2 diabetes susceptibility gene with a substantial effect on individual risk. Diabetes. 2006; 55:2640-4. [PubMed: 16936215]

[61]. Barber TM, Bennett AJ, Groves CJ, Sovio U, Ruokonen A, Martikainen H, Pouta A, Hartikainen AL, Elliott P, Wass JA, Jarvelin MR, Zeggini E, Franks S, McCarthy MI. Disparate genetic influences on polycystic ovary syndrome (PCOS) and type 2 diabetes revealed by a lack of association between common variants within the TCF7L2 gene and PCOS. Diabetologia. 2007; 50:2318-22. [PubMed: 17805508]

[62]. Ewens KG, Jones MR, Ankener W, Stewart DR, Urbanek M, Dunaif A, Legro RS, Chua A, Azziz R, Spielman RS, Goodarzi MO, Strauss JF 3rd. Type 2 diabetes susceptibility singlenucleotide polymorphisms are not associated with polycystic ovary syndrome. Fertil Steril. 2011

[63]. Liu X, Li L, Chen ZJ, Lu Z, Shi Y, Zhao Y. Genetic variants of cyclin-dependent kinase 5 regulatory subunit associated protein 1-like 1 and transcription factor 7-like 2 are not associated with polycystic ovary syndrome in Chinese women. Gynecol Endocrinol. 2010; 26:129-34. [PubMed: 19718565]

[64]. Xu P, Che Y, Cao Y, Wu X, Sun H, Liang F, Sun J, Ke L, Yi L, Wang Y. Polymorphisms of TCF7L2 and HHEX genes in Chinese women with polycystic ovary syndrome. J Assist Reprod Genet. 2010; 27:23-8. [PubMed: 20041287]

[65]. Christopoulos P, Mastorakos G, Gazouli M, Panidis D, Deligeoroglou E, Katsikis I, Papadias K, Diamandi-Kandarakis E, Creatsas G. Genetic variants in TCF7L2 and KCNJ11 genes in a Greek population with polycystic ovary syndrome. Gynecol Endocrinol. 2008; 24:486-90. [PubMed: 18958766]

[66]. Tan S, Scherag A, Janssen OE, Hahn S, Lahner H, Dietz T, Scherag S, Grallert H, Vogel CI, Kimmig R, Illig T, Mann K, Hebebrand J, Hinney A. Large effects on body mass index and 
insulin resistance of fat mass and obesity associated gene (FTO) variants in patients with polycystic ovary syndrome (PCOS). BMC Med Genet. 2010; 11:12. [PubMed: 20092643]

[67]. Biyasheva A, Legro RS, Dunaif A, Urbanek M. Evidence for association between polycystic ovary syndrome (PCOS) and TCF7L2 and glucose intolerance in women with PCOS and TCF7L2. J Clin Endocrinol Metab. 2009; 94:2617-25. [PubMed: 19351735]

[68]. Hanis CL, Boerwinkle E, Chakraborty R, Ellsworth DL, Concannon P, Stirling B, Morrison VA, Wapelhorst B, Spielman RS, Gogolin-Ewens KJ, Shepard JM, Williams SR, Risch N, Hinds D, Iwasaki N, Ogata M, Omori Y, Petzold C, Rietzch H, Schroder HE, Schulze J, Cox NJ, Menzel S, Boriraj VV, Chen X, Lim LR, Lindner T, Mereu LE, Wang YQ, Xiang K, Yamagata K, Yang Y, Bell GI. A genome-wide search for human non-insulin-dependent (type 2) diabetes genes reveals a major susceptibility locus on chromosome 2. Nat Genet. 1996; 13:161-6. [PubMed: 8640221]

[69]. Horikawa Y, Oda N, Cox NJ, Li X, Orho-Melander M, Hara M, Hinokio Y, Lindner TH, Mashima H, Schwarz PE, del Bosque-Plata L, Oda Y, Yoshiuchi I, Colilla S, Polonsky KS, Wei S, Concannon P, Iwasaki N, Schulze J, Baier LJ, Bogardus C, Groop L, Boerwinkle E, Hanis CL, Bell GI. Genetic variation in the gene encoding calpain-10 is associated with type 2 diabetes mellitus. Nat Genet. 2000; 26:163-75. [PubMed: 11017071]

[70]. Stumvoll M, Fritsche A, Madaus A, Stefan N, Weisser M, Machicao F, Haring H. Functional significance of the UCSNP-43 polymorphism in the CAPN10 gene for proinsulin processing and insulin secretion in nondiabetic Germans. Diabetes. 2001; 50:2161-3. [PubMed: 11522685]

[71]. Elbein SC, Chu W, Ren Q, Hemphill C, Schay J, Cox NJ, Hanis CL, Hasstedt SJ. Role of calpain-10 gene variants in familial type 2 diabetes in Caucasians. J Clin Endocrinol Metab. 2002; 87:650-4. [PubMed: 11836299]

[72]. Ridderstrale M, Nilsson E. Type 2 diabetes candidate gene CAPN10: first, but not last. Curr Hypertens Rep. 2008; 10:19-24. [PubMed: 18367022]

[73]. Gonzalez A, Abril E, Roca A, Aragon MJ, Figueroa MJ, Velarde P, Royo JL, Real LM, Ruiz A. Comment: CAPN10 alleles are associated with polycystic ovary syndrome. J Clin Endocrinol Metab. 2002; 87:3971-6. [PubMed: 12161543]

[74]. Gonzalez A, Abril E, Roca A, Aragon MJ, Figueroa MJ, Velarde P, Ruiz R, Fayez O, Galan JJ, Herreros JA, Real LM, Ruiz A. Specific CAPN10 gene haplotypes influence the clinical profile of polycystic ovary patients. J Clin Endocrinol Metab. 2003; 88:5529-36. [PubMed: 14602801]

[75]. Yilmaz M, Yurtcu E, Demirci H, Ergun MA, Ersoy R, Karakoc A, Yetkin I, Cakir N, Ayvaz G, Arslan M. Calpain 10 gene single-nucleotide 44 polymorphism may have an influence on clinical and metabolic features in patients with polycystic ovary syndrome. J Endocrinol Invest. 2009; 32:13-7. [PubMed: 19337008]

[76]. Vollmert C, Hahn S, Lamina C, Huth C, Kolz M, Schopfer-Wendels A, Mann K, Bongardt F, Mueller JC, Kronenberg F, Wichmann HE, Herder C, Holle R, Lowel H, Illig T, Janssen OE. Calpain-10 variants and haplotypes are associated with polycystic ovary syndrome in Caucasians. Am J Physiol Endocrinol Metab. 2007; 292:E836-44. [PubMed: 17106059]

[77]. Marquez JL, Pacheco A, Valdes P, Salazar LA. Association between CAPN10 UCSNP-43 gene polymorphism and polycystic ovary syndrome in Chilean women. Clin Chim Acta. 2008; 398:59. [PubMed: 18722363]

[78]. Lee JY, Lee WJ, Hur SE, Lee CM, Sung YA, Chung HW. 111/121 diplotype of Calpain-10 is associated with the risk of polycystic ovary syndrome in Korean women. Fertil Steril. 2009; 92:830-3. [PubMed: 18701098]

[79]. Wiltgen D, Furtado L, Kohek MB, Spritzer PM. CAPN10 UCSNP-43, UCSNP-19 and UCSNP-63 polymorphisms and metabolic syndrome in polycystic ovary syndrome. Gynecol Endocrinol. 2007; 23:173-8. [PubMed: 17454172]

[80]. Frayling TM, Timpson NJ, Weedon MN, Zeggini E, Freathy RM, Lindgren CM, Perry JR, Elliott KS, Lango H, Rayner NW, Shields B, Harries LW, Barrett JC, Ellard S, Groves CJ, Knight B, Patch AM, Ness AR, Ebrahim S, Lawlor DA, Ring SM, Ben-Shlomo Y, Jarvelin MR, Sovio U, Bennett AJ, Melzer D, Ferrucci L, Loos RJ, Barroso I, Wareham NJ, Karpe F, Owen KR, Cardon LR, Walker M, Hitman GA, Palmer CN, Doney AS, Morris AD, Smith GD, Hattersley AT, McCarthy MI. A common variant in the FTO gene is associated with body mass index and predisposes to childhood and adult obesity. Science. 2007; 316:889-94. [PubMed: 17434869] 
[81]. Scuteri A, Sanna S, Chen WM, Uda M, Albai G, Strait J, Najjar S, Nagaraja R, Orru M, Usala G, Dei M, Lai S, Maschio A, Busonero F, Mulas A, Ehret GB, Fink AA, Weder AB, Cooper RS, Galan P, Chakravarti A, Schlessinger D, Cao A, Lakatta E, Abecasis GR. Genome-wide association scan shows genetic variants in the FTO gene are associated with obesity-related traits. PLoS Genet. 2007; 3:e115. [PubMed: 17658951]

[82]. Dina C, Meyre D, Gallina S, Durand E, Korner A, Jacobson P, Carlsson LM, Kiess W, Vatin V, Lecoeur C, Delplanque J, Vaillant E, Pattou F, Ruiz J, Weill J, Levy-Marchal C, Horber F, Potoczna N, Hercberg S, Le Stunff C, Bougneres P, Kovacs P, Marre M, Balkau B, Cauchi S, Chevre JC, Froguel P. Variation in FTO contributes to childhood obesity and severe adult obesity. Nat Genet. 2007; 39:724-6. [PubMed: 17496892]

[83]. Thorleifsson G, Walters GB, Gudbjartsson DF, Steinthorsdottir V, Sulem P, Helgadottir A, Styrkarsdottir U, Gretarsdottir S, Thorlacius S, Jonsdottir I, Jonsdottir T, Olafsdottir EJ, Olafsdottir GH, Jonsson T, Jonsson F, Borch-Johnsen K, Hansen T, Andersen G, Jorgensen T, Lauritzen T, Aben KK, Verbeek AL, Roeleveld N, Kampman E, Yanek LR, Becker LC, Tryggvadottir L, Rafnar T, Becker DM, Gulcher J, Kiemeney LA, Pedersen O, Kong A, Thorsteinsdottir U, Stefansson K. Genome-wide association yields new sequence variants at seven loci that associate with measures of obesity. Nat Genet. 2009; 41:18-24. [PubMed: 19079260]

[84]. Adeyemo A, Chen G, Zhou J, Shriner D, Doumatey A, Huang H, Rotimi C. FTO genetic variation and association with obesity in West Africans and African Americans. Diabetes. 2010; 59:1549-54. [PubMed: 20299471]

[85]. Hotta K, Nakata Y, Matsuo T, Kamohara S, Kotani K, Komatsu R, Itoh N, Mineo I, Wada J, Masuzaki H, Yoneda M, Nakajima A, Miyazaki S, Tokunaga K, Kawamoto M, Funahashi T, Hamaguchi K, Yamada K, Hanafusa T, Oikawa S, Yoshimatsu H, Nakao K, Sakata T, Matsuzawa Y, Tanaka K, Kamatani N, Nakamura Y. Variations in the FTO gene are associated with severe obesity in the Japanese. J Hum Genet. 2008; 53:546-53. [PubMed: 18379722]

[86]. Chang YC, Liu PH, Lee WJ, Chang TJ, Jiang YD, Li HY, Kuo SS, Lee KC, Chuang LM. Common variation in the fat mass and obesity-associated (FTO) gene confers risk of obesity and modulates BMI in the Chinese population. Diabetes. 2008; 57:2245-52. [PubMed: 18487448]

[87]. Yajnik CS, Janipalli CS, Bhaskar S, Kulkarni SR, Freathy RM, Prakash S, Mani KR, Weedon MN, Kale SD, Deshpande J, Krishnaveni GV, Veena SR, Fall CH, McCarthy MI, Frayling TM, Hattersley AT, Chandak GR. FTO gene variants are strongly associated with type 2 diabetes in South Asian Indians. Diabetologia. 2009; 52:247-52. [PubMed: 19005641]

[88]. Barber TM, Bennett AJ, Groves CJ, Sovio U, Ruokonen A, Martikainen H, Pouta A, Hartikainen AL, Elliott P, Lindgren CM, Freathy RM, Koch K, Ouwehand WH, Karpe F, Conway GS, Wass JA, Jarvelin MR, Franks S, McCarthy MI. Association of variants in the fat mass and obesity associated (FTO) gene with polycystic ovary syndrome. Diabetologia. 2008; 51:1153-8. [PubMed: 18478198]

[89]. Yan Q, Hong J, Gu W, Zhang Y, Liu Q, Su Y, Li X, Cui B, Ning G. Association of the common rs9939609 variant of FTO gene with polycystic ovary syndrome in Chinese women. Endocrine. 2009; 36:377-82. [PubMed: 19859840]

[90]. Attaoua R, Ait El Mkadem S, Radian S, Fica S, Hanzu F, Albu A, Gheorghiu M, Coculescu M, Grigorescu F. FTO gene associates to metabolic syndrome in women with polycystic ovary syndrome. Biochem Biophys Res Commun. 2008; 373:230-4. [PubMed: 18572014]

[91]. Ewens KG, Jones MR, Ankener W, Stewart DR, Urbanek M, Dunaif A, Legro RS, Chua A, Azziz R, Spielman RS, Goodarzi MO, Strauss JF 3rd. FTO and MC4R gene variants are associated with obesity in polycystic ovary syndrome. PLoS One. 2011; 6:e16390. [PubMed: 21283731]

[92]. Kowalska I, Malecki MT, Straczkowski M, Skupien J, Karczewska-Kupczewska M, Nikolajuk A, Szopa M, Adamska A, Wawrusiewicz-Kurylonek N, Wolczynski S, Sieradzk J, Gorska M. The FTO gene modifies weight, fat mass and insulin sensitivity in women with polycystic ovary syndrome, where its role may be larger than in other phenotypes. Diabetes Metab. 2009; 35:32831. [PubMed: 19625203] 
[93]. Wehr E, Schweighofer N, Moller R, Giuliani A, Pieber TR, Obermayer-Pietsch B. Association of FTO gene with hyperandrogenemia and metabolic parameters in women with polycystic ovary syndrome. Metabolism. 2010; 59:575-80. [PubMed: 19913856]

[94]. Goodarzi MO, Dumesic DA, Chazenbalk G, Azziz R. Polycystic ovary syndrome: etiology, pathogenesis and diagnosis. Nat Rev Endocrinol. 2011; 7:219-31. [PubMed: 21263450]

[95]. Siiteri PK, Murai JT, Hammond GL, Nisker JA, Raymoure WJ, Kuhn RW. The serum transport of steroid hormones. Recent Prog Horm Res. 1982; 38:457-510. [PubMed: 6750727]

[96]. Ackerman CM, Lowe LP, Lee H, Chen F, Hughes E, Cholod P, Dyer AR, Hayes MG, Metzger BE, Lowe WL, Urbanek M. The role of the polycystic ovary syndrome susceptibility locus D19S884 allele 8 in maternal glycemia and fetal size. J Clin Endocrinol Metab. 2010; 95:324250. [PubMed: 20444918]

[97]. Bendlova B, Zavadilova J, Vankova M, Vejrazkova D, Lukasova P, Vcelak J, Hill M, Cibula D, Vondra K, Starka L, Vrbikova J. Role of D327N sex hormone-binding globulin gene polymorphism in the pathogenesis of polycystic ovary syndrome. J Steroid Biochem Mol Biol. 2007; 104:68-74. [PubMed: 17258903]

[98]. Ferk P, Teran N, Gersak K. The (TAAAA)n microsatellite polymorphism in the SHBG gene influences serum SHBG levels in women with polycystic ovary syndrome. Hum Reprod. 2007; 22:1031-6. [PubMed: 17189294]

[99]. Liu Q, Gu W, Cui B, Hong J, Zhang Y, Chi Z, Su Y, Ning G. The association of TAAAAn repeat polymorphism in sex hormone-binding protein gene with polycystic ovary syndrome in Chinese population. Endocrine. 2008; 34:62-7. [PubMed: 18937076]

[100]. Wickham EP 3rd, Ewens KG, Legro RS, Dunaif A, Nestler JE, Strauss JF 3rd. Polymorphisms in the SHBG gene influence serum SHBG levels in women with polycystic ovary syndrome. J Clin Endocrinol Metab. 2011; 96:E719-27. [PubMed: 21252242]

[101]. Xita N, Georgiou I, Lazaros L, Psofaki V, Kolios G, Tsatsoulis A. The role of sex hormonebinding globulin and androgen receptor gene variants in the development of polycystic ovary syndrome. Hum Reprod. 2008; 23:693-8. [PubMed: 18192296]

[102]. Xita N, Tsatsoulis A, Chatzikyriakidou A, Georgiou I. Association of the (TAAAA)n repeat polymorphism in the sex hormone-binding globulin (SHBG) gene with polycystic ovary syndrome and relation to SHBG serum levels. J Clin Endocrinol Metab. 2003; 88:5976-80. [PubMed: 14671199]

[103]. Perry JR, Weedon MN, Langenberg C, Jackson AU, Lyssenko V, Sparso T, Thorleifsson G, Grallert H, Ferrucci L, Maggio M, Paolisso G, Walker M, Palmer CN, Payne F, Young E, Herder C, Narisu N, Morken MA, Bonnycastle LL, Owen KR, Shields B, Knight B, Bennett A, Groves CJ, Ruokonen A, Jarvelin MR, Pearson E, Pascoe L, Ferrannini E, Bornstein SR, Stringham HM, Scott LJ, Kuusisto J, Nilsson P, Neptin M, Gjesing AP, Pisinger C, Lauritzen T, Sandbaek A, Sampson M, Zeggini E, Lindgren CM, Steinthorsdottir V, Thorsteinsdottir U, Hansen T, Schwarz P, Illig T, Laakso M, Stefansson K, Morris AD, Groop L, Pedersen O, Boehnke M, Barroso I, Wareham NJ, Hattersley AT, McCarthy MI, Frayling TM. Genetic evidence that raised sex hormone binding globulin (SHBG) levels reduce the risk of type 2 diabetes. Hum Mol Genet. 2010; 19:535-44. [PubMed: 19933169]

[104]. Ding EL, Song Y, Manson JE, Hunter DJ, Lee CC, Rifai N, Buring JE, Gaziano JM, Liu S. Sex hormone-binding globulin and risk of type 2 diabetes in women and men. N Engl J Med. 2009; 361:1152-63. [PubMed: 19657112]

[105]. Cousin P, Calemard-Michel L, Lejeune H, Raverot G, Yessaad N, Emptoz-Bonneton A, Morel Y, Pugeat M. Influence of SHBG gene pentanucleotide TAAAA repeat and D327N polymorphism on serum sex hormone-binding globulin concentration in hirsute women. J Clin Endocrinol Metab. 2004; 89:917-24. [PubMed: 14764814]

[106]. Hogeveen KN, Talikka M, Hammond GL. Human sex hormone-binding globulin promoter activity is influenced by a (TAAAA)n repeat element within an Alu sequence. J Biol Chem. 2001; 276:36383-90. [PubMed: 11473114]

[107]. Ackerman CM, Garcia OA, Legro RS, Dunaif A, Urbanek M. $S H B G$ (TAAAA)n Is Associated with Serum SHBG in a PCOS Case-Control Cohort. Endocr Rev. 2011; 32:P2-66. 03_Meeting Abstracts. 
[108]. Billings LK, Florez JC. The genetics of type 2 diabetes: what have we learned from GWAS? Ann N Y Acad Sci. 2010; 1212:59-77. [PubMed: 21091714]

[109]. Kosova G, Scott NM, Niederberger C, Prins GS, Ober C. Genome-wide Association Study Identifies Candidate Genes for Male Fertility Traits in Humans. Am J Hum Genet. 2012; 90:95061. [PubMed: 22633400]

[110]. McCarthy MI. Genomics, type 2 diabetes, and obesity. N Engl J Med. 2010; 363:2339-50. [PubMed: 21142536]

[111]. Swarr DT, Hakonarson H. Unraveling the complex genetic underpinnings of asthma and allergic disorders. Curr Opin Allergy Clin Immunol. 2010; 10:434-42. [PubMed: 20724923]

[112]. Van Winkel R, Esquivel G, Kenis G, Wichers M, Collip D, Peerbooms O, Rutten B, MyinGermeys I, Van Os J. REVIEW: Genome-wide findings in schizophrenia and the role of geneenvironment interplay. CNS Neurosci Ther. 2010; 16:e185-92. [PubMed: 20553308]

[113]. Chen ZJ, Zhao H, He L, Shi Y, Qin Y, Li Z, You L, Zhao J, Liu J, Liang X, Zhao X, Sun Y, Zhang B, Jiang H, Zhao D, Bian Y, Gao X, Geng L, Li Y, Zhu D, Sun X, Xu JE, Hao C, Ren CE, Zhang Y, Chen S, Zhang W, Yang A, Yan J, Ma J, Zhao Y. Genome-wide association study identifies susceptibility loci for polycystic ovary syndrome on chromosome 2p16.3, 2p21 and 9q33.3. Nat Genet. 2011; 43:55-9. [PubMed: 21151128]

[114]. Zeggini E, Scott LJ, Saxena R, Voight BF, Marchini JL, Hu T, de Bakker PI, Abecasis GR, Almgren P, Andersen G, Ardlie K, Bostrom KB, Bergman RN, Bonnycastle LL, Borch-Johnsen K, Burtt NP, Chen H, Chines PS, Daly MJ, Deodhar P, Ding CJ, Doney AS, Duren WL, Elliott KS, Erdos MR, Frayling TM, Freathy RM, Gianniny L, Grallert H, Grarup N, Groves CJ, Guiducci C, Hansen T, Herder C, Hitman GA, Hughes TE, Isomaa B, Jackson AU, Jorgensen T, Kong A, Kubalanza K, Kuruvilla FG, Kuusisto J, Langenberg C, Lango H, Lauritzen T, Li Y, Lindgren CM, Lyssenko V, Marvelle AF, Meisinger C, Midthjell K, Mohlke KL, Morken MA, Morris AD, Narisu N, Nilsson P, Owen KR, Palmer CN, Payne F, Perry JR, Pettersen E, Platou C, Prokopenko I, Qi L, Qin L, Rayner NW, Rees M, Roix JJ, Sandbaek A, Shields B, Sjogren M, Steinthorsdottir V, Stringham HM, Swift AJ, Thorleifsson G, Thorsteinsdottir U, Timpson NJ, Tuomi T, Tuomilehto J, Walker M, Watanabe RM, Weedon MN, Willer CJ, Illig T, Hveem K, Hu FB, Laakso M, Stefansson K, Pedersen O, Wareham NJ, Barroso I, Hattersley AT, Collins FS, Groop L, McCarthy MI, Boehnke M, Altshuler D. Meta-analysis of genome-wide association data and large-scale replication identifies additional susceptibility loci for type 2 diabetes. Nat Genet. 2008; 40:638-45. [PubMed: 18372903]

[115]. Yoshimura S, Gerondopoulos A, Linford A, Rigden DJ, Barr FA. Family-wide characterization of the DENN domain Rab GDP-GTP exchange factors. J Cell Biol. 191:367-81. [PubMed: 20937701]

[116]. Lerchbaum E, Trummer O, Giuliani A, Gruber HJ, Pieber TR, Obermayer-Pietsch B. Susceptibility loci for polycystic ovary syndrome on chromosome 2p16.3, 2p21, and 9q33.3 in a cohort of Caucasian women. Horm Metab Res. 2011; 43:743-7. [PubMed: 22009367]

[117]. Eriksen MB, Brusgaard K, Andersen M, Tan Q, Altinok ML, Gaster M, Glintborg D. Association of polycystic ovary syndrome susceptibility single nucleotide polymorphism rs 2479106 and PCOS in Caucasian patients with PCOS or hirsutism as referral diagnosis. Eur J Obstet Gynecol Reprod Biol. 2012; 163:39-42. [PubMed: 22504079]

[118]. Goodarzi MO, Jones MR, Li X, Chua AK, Garcia OA, Chen YD, Krauss RM, Rotter JI, Ankener W, Legro RS, Azziz R, Strauss JF 3rd, Dunaif A, Urbanek M. Replication of association of DENND1A and THADA variants with polycystic ovary syndrome in European cohorts. J Med Genet. 2012; 49:90-5. [PubMed: 22180642]

[119]. Welt CK, Styrkarsdottir U, Ehrmann DA, Thorleifsson G, Arason G, Gudmundsson JA, Ober C, Rosenfield RL, Saxena R, Thorsteinsdottir U, Crowley WF, Stefansson K. Variants in DENND1A Are Associated with Polycystic Ovary Syndrome in Women of European Ancestry. J Clin Endocrinol Metab. 2012

[120]. Pritchard JK, Cox NJ. The allelic architecture of human disease genes: common diseasecommon variant...or not? Hum Mol Genet. 2002; 11:2417-23. [PubMed: 12351577]

[121]. Wang Z, Gerstein M, Snyder M. RNA-Seq: a revolutionary tool for transcriptomics. Nat Rev Genet. 2009; 10:57-63. [PubMed: 19015660] 
[122]. Li Z, Huang H. Epigenetic abnormality: a possible mechanism underlying the fetal origin of polycystic ovary syndrome. Med Hypotheses. 2008; 70:638-42. [PubMed: 17764855]

[123]. Laird PW. Principles and challenges of genomewide DNA methylation analysis. Nat Rev Genet. 2010; 11:191-203. [PubMed: 20125086]

[124]. Genomes. http://www.1000genomes.org/

[125]. Human Genome Diversity Project. http://hagsc.org/hgdp/

[126]. Moran LJ, Pasquali R, Teede HJ, Hoeger KM, Norman RJ. Treatment of obesity in polycystic ovary syndrome: a position statement of the Androgen Excess and Polycystic Ovary Syndrome Society. Fertil Steril. 2009; 92:1966-82. [PubMed: 19062007]

[127]. Vandenberg LN, Maffini MV, Sonnenschein C, Rubin BS, Soto AM. Bisphenol-A and the great divide: a review of controversies in the field of endocrine disruption. Endocr Rev. 2009; 30:7595. [PubMed: 19074586]

[128]. Diamanti-Kandarakis E, Bourguignon JP, Giudice LC, Hauser R, Prins GS, Soto AM, Zoeller RT, Gore AC. Endocrine-disrupting chemicals: an Endocrine Society scientific statement. Endocr Rev. 2009; 30:293-342. [PubMed: 19502515]

[129]. Pasquali R, Stener-Victorin E, Yildiz BO, Duleba AJ, Hoeger K, Mason H, Homburg R, Hickey T, Franks S, Tapanainen JS, Balen A, Abbott DH, Diamanti-Kandarakis E, Legro RS. PCOS Forum: research in polycystic ovary syndrome today and tomorrow. Clin Endocrinol (Oxf). 2011; 74:424-33. [PubMed: 21158892] 


\section{BOX 1. Current Challenges in Genetic Studies of PCOS}

- Phenotypic heterogeneity

PCOS cohorts are usually comprised of a phenotypically heterogeneous group of subjects, due to the broad range of reproductive (hyperandrogenemia, menstrual irregularity and polycystic ovaries) and metabolic symptoms (insulin resistance, obesity, T2DM, dyslipidemia) they exhibit, variability in the commonly used diagnostic criteria, and the subjective nature in evaluation of certain symptoms (i.e. hirsutism, acne). Because the underlying pathophysiologies for different PCOS phenotypes may differ from each other, susceptibility genes affecting these phenotypes may also be different, which decreases our ability to identify contributing genetic factors.

- Environmental confounders

In complex traits like PCOS, it is often impossible to fully identify all the nongenetic contributors to the observed phenotype, and accurately quantify their effects. Lifestyle modifications, such as weight loss and moderate exercise may alter phenotypic expression of PCOS substantially [126]. Contributions of other factors, such as exposure to certain chemicals, are still under debate [127-129]. As a result, dissecting out effects of individual genes (or loci) from other unknown factors presents a major challenge.

- Genetic heterogeneity

It is a common feature of complex traits to be influenced by many genes, each with small effects. These genes may each contribute separately, or they might act collectively (i.e. have roles in the same pathways or result in the same downstream effects). Furthermore, different variation in the same gene may have similar effect on gene function (allelic heterogeneity). Because many of the existing methods consider the contribution of each locus independently (rather than as a whole) for a gene or a pathway, detecting significant effects from all possible causal loci is often not possible.

- Unknown nature of gene-gene and gene-environment interactions

Gene by gene, and/or gene by environment interactions also likely have roles in disease outcome. However, most of these interactions are not yet known, and with the current statistical methods, it is very difficult to detect such interactions in the absence of a priori hypothesis.

- Small sample size

Recruitment of sufficiently large cohorts, which would provide enough power to detect genes with small effects, is difficult because of the inherent characteristics of the disorder. PCOS can only be reliably diagnosed in women who are reproductive age and not on several common medications (such as oral contraceptives). There is no accepted PCOS-equivalent diagnosis for men; and because PCOS is associated with reduced fertility, large families with multiple affected sister pairs are uncommon, therefore, family based genetic studies are often not feasible.

- Limitations of commonly used approaches

To date, candidate gene analyses have been the predominant approach used in PCOS genetics. Although several very promising PCOS susceptibility genes (or 
loci) have been identified by this method (also discussed in this review), no single gene has been successfully replicated and identified as truly causative across all studies. Among the reasons for lack of replication are inadequate sample sizes which could lead to false positive or false negative findings, and incomplete coverage of the candidate gene (i.e. many studies testing associations with just a few variants in each gene). Lastly, the candidate gene approach can be useful only when there is an a priori hypothesis about involvement of a given gene in the etiology of PCOS because of its known function; consequently, it falls short of identifying novel genes or genes whose functions are less well characterized. On the other hand, although studies designed to capture the complete variation in these genes (such as GWAS and NGS) are becoming more feasible, they still face other problems, including high genotyping costs and multiple testing adjustments. 


\section{HIGHLIGHTS}

- PCOS is a highly complex disorder with reproductive and metabolic consequences.

- Disease heterogeneity and small sample sizes complicate the identification of causal PCOS genes.

- Candidate gene association studies have been the common approach in PCOS research.

- Development of new methods including GWAS and NGS offers promising progress in identifying PCOS genes. 